\title{
Unstained Specimen
}

National Cancer Institute

\section{Source}

National Cancer Institute. Unstained Specimen. NCI Thesaurus. Code C62755.

A specimen that is mounted for microscopic study but without preparation methods which use dyes, reagents or other materials to produce coloration in tissues or microorganisms for microscopic examination. 